\title{
Xenofobie onder jongeren: de invloed van interetnisch contact
}

\author{
Hidde Bekhuis, Stijn Ruiter, en Marcel Coenders ${ }^{1}$
}

\section{Summary}

Xenophobia among youngsters: the influence of interethnic contact.

This study examines xenophobic attitudes of high school pupils. It answers the questions: To what extent do high school pupils from different ethnic backgrounds hold xenophobic attitudes? And to what are these attitudes related with interethnic contact? Scientific progress is made in three ways. Firstly, attitudes of high school pupils from both the ethnic majority (Dutch) and the ethnic minority groups (Turks, Moroccans, and Caribbean) are examined. Secondly, the impact of positive as well as negative interethnic contact within and outside the school environment is determined. And thirdly, hypotheses about interethnic contact are tested while simultaneously controlling for alternative mechanisms that explain xenophobic attitudes. The results show that most pupils have a low level of xenophobia. In addition, the level of xenophobia is less when pupils evaluate their interethnic contacts both within and outside the school environment as positive and higher when they perceive these contacts as negative. However, the impact of positive interethnic contact in class disappears or even reverses when multiculturalism is stressed more during lessons.

\section{Inleiding}

De houding van jongeren ten aanzien van personen van een andere etnische afkomst, en hun houding ten aanzien van de (Nederlandse) multiculturele samenleving hebben recentelijk de aandacht getrokken van verschillende onderzoekers (zie onder andere Bakker, Denessen, Pelzer, Veneman \& Lageweg, 2007; Dekker, Van der Noll \& Capelos, 2007; Peters, Haest \& Walraven, 2008; Verkuyten, 2005, 2007). Deze aandacht is begrijpelijk aangezien jongeren de toekomst van de samenleving vormen en er in Nederland sprake lijkt te zijn van een groeiende kloof tussen mensen van verschillende etnische afkomst (CBS/WODC, 2006). 
De meeste studies naar de houding en mening van jongeren over andere etnische groepen en de multiculturele samenleving richten zich op de xenofobe houding van jongeren en bestuderen de invloed van interetnisch contact in de klas en school (Bakker et al., 2007; Dekker et al., 2007; Verkuyten, 2005, 2007). In deze studies wordt interetnisch contact beschouwd als het directe contact met personen van een andere etnische afkomst. Bakker en et al. (2007) laten bijvoorbeeld zien dat de etnische samenstelling van de klas - en daarmee de mogelijkheden voor interetnisch contact - niet van invloed is op de xenofobe houding van basisschoolleerlingen. Baerveldt et al. (2004) daarentegen benadrukken juist het belang van het hebben van mogelijkheden tot interetnisch contact in de klas. Ook Dekker et al. (2007) tonen dat de houding van autochtone jongeren ten aanzien van moslims juist verbetert wanneer zij positief contact met moslims hebben. Deze tegenstrijdige resultaten omtrent het belang van interetnisch contact zouden ondermeer verklaard kunnen worden door het verschil in leeftijd van de onderzochte jongeren. Het is namelijk leeftijdsafhankelijk in hoeverre een leerling een eigen mening heeft ontwikkeld, of dat deze de mening van zijn of haar ouders overneemt (Steinberg \& Silverberg, 1986). Tevens bepaalt leeftijd ook de mate waarin iemand de mogelijkheid heeft gehad om interetnisch contact te hebben en ervaringen op te doen met mensen van verschillende (etnische) komaf (Dekker et al., 2007). Naast verschillen in leeftijd van de onderzochte jongeren zouden de verschillende onderzoeksresultaten ook voort kunnen komen uit het gebruik van verschillende afhankelijke variabelen alsmede de verschillende manieren waarop in de onderzoeken gecontroleerd wordt voor andere relevante factoren zoals de ervaren culturele- en sociaaleconomische dreiging (zie ondermeer Coenders, 2001; Lubbers, Coenders \& Scheepers, 2006; Scheepers, Gijsberts \& Coenders, 2002), en achtergrondkenmerken zoals opleidingsniveau en persoonlijkheid (zie ondermeer Dekker, Malova \& Hoogendoorn, 2003; Pettigrew \& Tropp, 2006). In deze studie bestuderen we de invloed van interetnisch contact op de xenofobe houding van leerlingen uit de vierde klas van de middelbare school, waarbij we uitgebreid controleren voor ondermeer de hoogte van de opleiding die de leerlingen volgen, bepaalde persoonlijkheidskenmerken en de ervaren culturele en sociaaleconomische dreiging.

Recentelijk heeft Van der Meulen (2007) het onderzoek naar de invloed van interetnisch contact verrijkt door aan te tonen dat naast interetnisch contact in de klas, op school en in de buurt ook interetnisch contact op sportverenigingen de houding van autochtonen ten aanzien van allochtonen positief kan beïnvloeden. Onderzoek waarin tegelijkertijd wordt gekeken naar de invloed van contact in verschillende settings (zoals klas, school, buurt en sportvereniging c.q. vrijetijdsvereniging) ontbreekt ech- 
ter tot op heden (Pettigrew \& Tropp, 2006). Wij boeken hierop vooruitgang door gelijktijdig te onderzoeken wat de invloed is van interetnisch contact in de klas, op school, in de buurt en op vrijetijdsverenigingen op de xenofobe houdingen van jongeren.

In nagenoeg alle studies die het verband tussen interetnisch contact en xenofobe houdingen bestuderen, wordt slechts gekeken naar de invloed van positief interetnisch contact (Pettigrew \& Tropp, 2006). Hierdoor is er enkel kennis over de invloed van interetnisch contact dat ervaren wordt als plezierig en leuk, en dat dus voor herhaling vatbaar is. Of en hoe negatief interetnisch contact - contact dat ervaren wordt als onplezierig en onprettig, en dat in de toekomst liever vermeden zal worden - xenofobe houdingen beïnvloedt, is nog onbekend. In deze studie kijken we naar de invloed van zowel positief als negatief interetnisch contact.

Verreweg de meeste kennis over de beïnvloeding en verklaring van houdingen ten aanzien van andere etnische groepen is verkregen uit onderzoek vanuit het meerderheidsperspectief; de houdingen van voornamelijk de etnische meerderheid, autochtonen, zijn bestudeerd. Daarmee is het nog onbekend of de algemeen aanvaarde hypothese dat (positief) contact resulteert in een positieve houding ook opgaat bij etnische minderheden (Van Tubergen, 2006). Om meer inzicht te krijgen in de houdbaarheid van deze hypothese kijken we in deze studie naar de houding van zowel autochtone als allochtone leerlingen.

Kort samengevat boeken we in deze studie dus op drie manieren vooruitgang ten opzichte van eerder onderzoek. Allereerst richten we ons op de xenofobe houding van zowel autochtone als allochtone jongeren. Daarnaast gaan we na wat de invloed is van positief en negatief contact in verschillende contactsituaties. En ten slotte toetsen we onze hypothesen aangaande interetnisch contact terwijl we simultaan controleren voor belangrijke kenmerken die eveneens voorspellend zijn voor het hebben van een xenofobe houding en die ook samen kunnen gaan met het hebben van (positieve of negatieve) interetnische contacten. In deze studie beantwoorden we dan ook de volgende vraag: In welke mate hebben middelbare scholieren op verschillende opleidingsniveaus en met verschillende etnische achtergronden een xenofobe attitude? En in hoeverre bestaat er een samenhang tussen deze attitude en positief en negatief interetnisch contact in de klas, op school, bij vrijetijdsverenigingen en in de buurt? 


\section{Theorie en hypothesen}

\section{Positief contact}

Het ontbreken van interetnisch contact is altijd beschouwd als een belangrijke verklaring voor het hebben van etnische vooroordelen. De bekendste en tevens algemeen aanvaarde hypothese omtrent de werking van interetnisch contact volgt uit Allports (1954) contacttheorie. Allport baseert zijn theorie op de eerste empirische studies naar de invloed van contact en vat deze als volgt samen: direct contact tussen leden van verschillende groepen vermindert vooroordelen wanneer er aan de volgende vier criteria is voldaan: er moet sprake zijn van een gelijke status tussen de verschillende groepen; er moet sprake zijn van gelijke doelen die de groepen nastreven; er moet sprake zijn van samenwerking tussen de verschillende groepen; en er moet sprake zijn van ondersteuning door wetgeving of autoriteiten.

In een meta-analyse van 515 studies die Allports contacttheorie toetsen, tonen Pettigrew en Tropp (2006) aan dat positief ervaren contact inderdaad vooroordelen en negatieve houdingen doet verminderen. De vier door Allport noodzakelijk geachte voorwaarden blijken echter niet essentieel te zijn. De aanwezigheid van één of meerdere door Allport veronderstelde 'noodzakelijke' condities blijken enkel het effect van positief contact te versterken (McLaren, 2003; Pettigrew \& Tropp, 2006). Dit betekent dus dat positief contact negatieve houdingen en vooroordelen te allen tijde doet verkleinen. Maar wanneer één of meerdere 'noodzakelijke' voorwaarden aanwezig zijn, worden negatieve houdingen en vooroordelen door positief interetnisch contact nog sterker verkleind dan wanneer deze afwezig zijn.

Positief interetnisch contact draagt dus bij aan een gunstigere houding ten aanzien van personen van andere etnische groepen. De vraag is echter of meer interetnisch contact tot een tolerantere houding leidt, of andersom, dat mensen met een tolerantere houding meer interetnisch contact krijgen, en deze contacten bovendien als positiever ervaren. In het laatste geval is er sprake van selectie en hoeft een negatieve samenhang tussen interetnisch contact en xenofobe attitudes geenszins te wijzen op een ondersteuning van Allports contacthypothese. Vanwege dit causaliteitsprobleem is het van belang om allereerst naar de mogelijkheden tot interetnisch contact te kijken. De mogelijkheid om contact aan te gaan is immers een voorwaarde voor positief interetnisch contact, wat op zijn beurt de houding ten aanzien van andere etnische groepen positief zou moeten beïnvloeden (Pettigrew \& Tropp, 2006). De eerste hypothesen hebben dan ook betrekking op de mogelijkheid tot het hebben van interetnisch contact in relevante sociale settings van leerlingen: hun klas en hun buurt. Ervan uitgaande dat deze contacten positief zijn, luiden de hypothesen over contactmogelijkheden als volgt: 
1. Leerlingen in etnisch meer heterogene klassen hebben minder xenofobe houdingen.

2. Leerlingen die wonen in etnisch meer heterogene buurten, hebben minder xenofobe houdingen.

Door enkel naar de mogelijkheid tot interetnisch contact te kijken wordt echter niet bekend of dit contact daadwerkelijk plaatsvindt, noch hoe de causale relatie tussen interetnisch contact en de xenofobe houding loopt. Deze problemen kunnen grotendeels worden verholpen door na te gaan wat de invloed is van interetnische contacten in een situatie waarin jongeren gedwongen samen zijn. Dergelijke gedwongen interetnische contacten, zoals contacten in de klas, kunnen moeilijk worden vermeden, waarmee etnische voorkeurenniet of nauwelijks een rol kunnen spelen bij het aangaan van deze contacten. De omgekeerde causale relatie wordt hiermee in belangrijke mate uitgesloten, waardoor we Allports contacthypothese ook zonder een longitudinaal design aan een toetsing kunnen onderwerpen(Dekker et al., 2007; Pettigrew \& Tropp, 2006).

Leerlingen kunnen interetnische contacten in hun klas moeilijk vermijden. Contact vindt echter niet alleen plaats in de gedwongen setting van de klas. Contacten vinden ook plaats elders op school, in de buurt en op sport- en vrijetijdsverenigingen. De mogelijkheden om contacten te vermijden zijn per situatie verschillend. Zo zullen sommige jongeren waarschijnlijk bewust bepaalde sportverenigingen mijden, omdat er naar hun mening teveel jongeren van een andere etniciteit sporten. Interetnische contacten op sportverenigingen zijn daarmee dus redelijk gemakkelijk te vermijden; gemakkelijker dan die in de buurt waarin men woont. Het is immers geen verplichting om naar een sportvereniging te gaan, maar de buurt waarin men woont, kan men veel moeilijker verlaten. Interetnische contacten in de buurt kunnen op hun beurt waarschijnlijk weer gemakkelijker vermeden worden dan contacten op school. Een schoolgebouw is immers kleiner dan een wijk. Doordat contacten op sportverenigingen het makkelijkst kunnen worden vermeden, en in de klas het moeilijkst, is de kans dat een positieve houding de mate van interetnisch contact bepaalt - en er dus sprake is van een omgekeerde causale relatie - het grootst bij contact op sportverenigingen en het kleinst bij contact in de klas. Ondanks dat de kans op een omgekeerde causale relatie bij contacten op school, in de buurt en op sportverenigingen alsmaar toeneemt, tonen zowel McLaren (2003) als Pettigrew en Tropp (2006) aan dat positief contact in al deze settings de houding ten aanzien van andere etnische groepen substantieel beïnvloedt. Naar onze mening dienen we dan ook geenszins af te zien van de bestudering van 
deze verschillende contactsituaties, omdat er mogelijk sprake is van een omgekeerde causale relatie. Integendeel, door juist rekening te houden met de mate waarin interetnisch contact meer of minder gedwongen is, konden we Allports contacthypothese beter toetsen (Pettigrew \& Tropp, 2006). We formuleerden hypothesen omtrent de invloed van interetnisch contact in de klas, op school, in de buurt en op vrijetijdsverenigingen op de mate waarin jongeren er xenofobe houdingen op nahouden, terwijl we bij de toetsing ervan dus continu in ons achterhoofd moeten houden dat de mogelijkheid op omgekeerde causaliteit verschilt al naar gelang de bestudeerde setting. Aangaande positieve interetnische contacten luidt onze hypothese als volgt:

3. Leerlingen die meer positief interetnisch contact hebben in hun (a) klas, (b) school, (c) buurt en (d) vrijetijdsvereniging hebben een minder xenofobe houding.

\section{Negatief contact}

De invloed van positief interetnisch contact op de houding ten aanzien van mensen van een andere afkomst is al veel vaker onderzocht. Dit in tegenstelling tot de invloed van negatief contact (Pettigrew \& Tropp, 2006). Omdat positief interetnisch contact negatieve houdingen zou verminderen en vooroordelen zou wegnemen is het logisch te veronderstellen dat negatief interetnisch contact een negatieve houding juist versterkt en vooroordelen vergroot (Cameron, Rutland, Brown \& Douch, 2006; Pettigrew \& Tropp, 2006). We formuleerden dan ook de volgende hypothese:

4. Leerlingen die meer negatief interetnisch contact hebben in hun (a) klas, (b) school, (c) buurt en (d) vrijetijdsvereniging hebben een meer xenofobe houding.

\section{Positief versus negatief contact}

Uit enkele van de weinige studies naar de invloed van negatieve ervaringen en contacten is al wel gebleken dat negatieve ervaringen en contacten de effecten van positieve ervaringen en contacten kunnen verkleinen of zelfs tenietdoen. Zo laten Nesdale (1999) en Vrij, Akehurst en Smith (2003) met psychologische experimenten zien dat negatieve informatie en ervaringen de vooroordelen sterker beïnvloeden dan positieve informatie en ervaringen. Dit doet vermoeden dat meer negatief interetnisch contact niet alleen leidt tot een meer xenofobe houding, maar ook dat het effect van negatief contact sterker is dan het effect van positief contact. We formuleerden dan ook de volgende hypothese: 
5. Negatief interetnisch contact is sterker gerelateerd aan de xenofobe houding van leerlingen dan positief interetnisch contact.

Niet alleen zou de invloed van negatief contact sterker kunnen zijn dan van positief contact, ook zou het hebben van negatief contact in een bepaalde setting, bijvoorbeeld de buurt, het effect van positief contact in een andere setting, bijvoorbeeld de klas, kunnen verkleinen. Yogev, Ben-Yehoshua en Alper (1991) laten in hun studie naar het geloof op een vreedzame Palestijns-Israëlische toekomst onder Palestijnse jongeren zien dat de positieve contacten met Israëlische jongeren op school niet langer positief van invloed zijn wanneer zijzelf of bekenden van hun in aanraking zijn gekomen met Israëlisch geweld. Als we deze bevinding vertalen naar onze studie, zou het kunnen zijn dat het effect van positief interetnisch contact in de klas kleiner is of zelfs afwezig wanneer jongeren in hun buurt negatief interetnisch contact hebben. De hypothese over zulk soort situatieoverstijgende effecten van negatief contact luidt daarmee als volgt:

6. Negatief interetnisch contact in een bepaalde situatie verkleint de invloed van positief contact in een andere situatie.

De mate waarin scholen aandacht besteden aan de multiculturele samenleving Op school komen leerlingen in aanraking met het beleid van hun school ten aanzien van de stimulering en wenselijkheid van de multiculturele samenleving. Of scholen aandacht besteden aan de multiculturele samenleving en de mate waarin dit gebeurt, kan worden beschouwd als de mate van aanmoediging door autoriteiten (Verkuyten \& Thijs, 2002b). Aangezien aanmoediging door de wet, autoriteiten of instituties één van Allports vier 'noodzakelijke' contactcondities betreft die het effect van positief contact doen versterken, konden we hypothesen over de invloed van het schoolbeleid ten aanzien van de multiculturele samenleving formuleren. Deze luiden als volgt:

7. Het effect van positief contact in de (a) klas en op (b) school is sterker op scholen die meer aandacht besteden aan de multiculturele samenleving.

8. Het effect van negatief contact in de (a) klas en op (b) school is kleiner op scholen die meer aandacht besteden aan de multiculturele samenleving. 


\section{Het belang van de contactsituatie}

Het ligt in de rede dat contacten waaraan meer belang wordt gehecht in het algemeen de houding van personen meer beïnvloeden dan contacten die minder belangrijk worden gevonden. Zo vinden Van Dick en collega's (2004) dat naarmate interetnische contacten meer bijdragen aan het behalen van persoonlijke doelen, en dus belangrijker zijn, dat de invloed van deze contacten op de xenofobe houding toeneemt. Volgens deze redenering zou de sterkte van het effect van interetnisch contact tussen de bovengenoemde settings - klas, school, buurt en vrijetijdsverenigingen - dus kunnen verschillen.

$\mathrm{Na}$ het contact met ouders kunnen contacten in de klas over het algemeen als het belangrijkst worden beschouwd voor leerlingen op de middelbare school. Leerlingen moeten namelijk bijna dagelijks samenwerken met hun klasgenoten. Daarnaast kunnen klasgenoten elkaar helpen met huiswerk en kunnen vriendschappen met klasgenoten zorgen voor een leuke en aangename schooltijd (Hargreaves, 1967; Ladd, 1990; Newman \& Schwager, 1993). Ook contacten op school, in de buurt en op vrijetijdsverenigingen zijn van belang voor leerlingen. Deze contacten zorgen immers ook voor vriendschappen (Ladd, 1990). Toch zijn deze contacten over het algemeen van minder belang dan de contacten in de klas, omdat contacten in de klas namelijk meer functies hebben dan alleen vriendschap (Hargreaves, 1967).

Het belang van contacten op school, in de buurt en op vrijetijdsverenigingen is sterk afhankelijk van de thuissituatie, de interesses en de persoonlijkheid van de leerling (Junger-Tas, 1992; Ladd, 1990; Nesdale \& Todd, 200o). Zo hechten leerlingen uit minder welvarende gezinnen die wonen in sociaaleconomisch zwakkere buurten meer belang aan de contacten uit hun buurt (Junger-Tas, 1992), blijken leerlingen met meer sportieve of culturele ambities het contact op sport- en vrijetijdsverenigingen belangrijker te vinden (Ladd, 1990), en is het contact op school voor introvertere leerlingen belangrijker dan het contact in de buurt of op vrijetijdsverenigingen (Nesdale \& Todd, 20oo). Onze hypothese omtrent het belang van de contactsituatie maakt vanwege deze complexiteit geen onderscheid tussen contact op school, in de buurt en op vrijetijdsverenigingen en luidt als volgt:

9. Interetnisch contact in de klas heeft een groter effect op de xenofobe houding dan interetnisch contact op school, in de buurt, en op vrijetijdsverenigingen. 


\section{Data en meetinstrumenten}

Data

Voor de beschrijving en verklaring van xenofobe houdingen van zowel autochtone als allochtone jongeren op verschillende opleidingsniveaus was het noodzakelijk om nieuwe data te verzamelen. In mei 2007 werd de directeuren van dertien VMBO-, HAVO-, en VWO-scholen van het 'Samenwerkingsverband VO Nijmegen en omgeving' gevraagd om toestemming voor het afnemen van de schriftelijke enquête 'Scholieren over zichzelf en elkaar, 2007' onder al hun leerlingen in de vierde klas. Scholen die alleen praktijkonderwijs en/of de LWOO leerweg aanboden, zijn niet benaderd omdat de vragenlijst waarschijnlijk te complex was voor de leerlingen op deze niveaus.

Om uiteenlopende redenen weigerden drie directeuren toestemming te verlenen aan het onderzoek. De hier gebruikte gegevens van 1444 autochtone en allochtone leerlingen zijn dan ook verzameld op tien verschillende scholen. De leerlingen zaten in 77 verschillende klassen en woonden in 117 verschillende postcodegebieden (4-cijfer). Deze postcodegebieden beschouwden we als de buurt waarin de leerling woont. Van de leerlingen volgden 268 (18,6\%) de VMBO gemengde, kader of beroepsgerichte leerweg, 319 leerlingen $(21,9 \%)$ volgden de VMBO theoretische leerweg, 545 leerlingen $(37,7 \%)$ zaten op de HAVO en 315 leerlingen $(21,8 \%)$ zaten op het VWO.

\section{Meetinstrumenten afhankelijke en onafhankelijke variabelen}

Om de etniciteit van de leerlingen te bepalen is ze gevraagd aan te geven in hoeverre ze zich Nederlander, Surinamer, Antilliaan, Marokkaan, Turk of 'anders' voelen. ${ }^{2}$ Leerlingen hadden hierbij de keus uit vijf antwoordcategorieën, oplopend van helemaal niet tot heel sterk. De etnische groep waarmee leerlingen zich het sterkst identificeerden, is beschouwd als de etniciteit van de leerling. Sommige leerlingen identificeerden zichzelf echter even sterk met de Nederlandse etniciteit als met een andere etniciteit. In deze gevallen is de leerling tot de niet-Nederlandse etniciteit gerekend. Het is namelijk waarschijnlijk dat deze leerlingen zichzelf niet volledig Nederlands voelen noch volledig als Nederlander worden beschouwd en behandeld. Ten slotte bleek het aantal leerlingen dat volgens deze operationalisering Surinaams of Antilliaans is, relatief klein te zijn, respectievelijk o,8 en 1,1\%. Deze twee etnische groepen zijn voor de analyses dan ook samengevoegd tot de Caribische etniciteit.

Bij de constructie van de overige meetinstrumenten was het noodzakelijk om na te gaan of de verschillende meetinstrumenten voor de verschillende etnische achtergronden hetzelfde concept meten en of dit 
even betrouwbaar gebeurt. Factoranalyses en betrouwbaarheidsanalyses zijn bij de constructie van de meetinstrumenten daarom afzonderlijk verricht voor leerlingen die zichzelf als Nederlander beschouwen $(\mathrm{n}=$ 1.129) en voor leerlingen die zichzelf als niet-Nederlander beschouwen $(n=315)$. Deze separate analyses lieten geen substantiële verschillen zien in factorstructuur en betrouwbaarheid tussen deze twee groepen. De hieronder beschreven meetinstrumenten blijken daarmee geschikt te zijn voor zowel leerlingen die zichzelf als Nederlander beschouwen als voor leerlingen die zich niet als Nederlander beschouwen.

De afhankelijke variabele in deze studie, de xenofobe houding van leerlingen, werd gemeten door middel van etnische distantie. Etnische distantie is de neiging die iemand heeft om contact met andere (etnische) groepen in verschillende situaties te vermijden. De xenofobe houding van leerlingen is op deze manier gemeten, omdat etnische distantie gemeten kan worden met behulp van concrete vragen die geen beroep doen op voorkennis of abstract redeneren. Dit maakt het uitermate geschikt voor leerlingen van verschillende opleidingsniveaus (Hello, Scheepers, Vermulst, \& Gerris, 2004; Nigbur et al., 2007; Postma, 2007). Leerlingen werd gevraagd om op een vijfpuntsschaal aan te geven in hoeverre zij bezwaar zouden hebben om een relatie aan te gaan met, buren te zijn van, vriendschap te hebben met, schoonfamilie te zijn van, les te krijgen van, vrienden van vrienden te zijn van, en op een vereniging te zitten met mensen van een andere afkomst dan de eigen afkomst. Om zeker te zijn dat leerlingen mensen van een andere afkomst interpreteerden als mensen van een andere etnische afkomst dan de eigen afkomst, is bij de introductie van deze vraag een aantal voorbeelden gegeven om dit te verduidelijken. Factoranalyse toonde aan dat deze zeven items refereren aan één dimensie. Verder bleken deze items een betrouwbare schaal te vormen (Cronbachs alfa is 0,84 ). De mate van etnische distantie is berekend door het gemiddelde van deze zeven items te nemen. Deze schaal loopt van een (1), geen etnische distantie, tot vijf (5), extreme etnische distantie. De gemiddelde score op deze schaal is 1,89 en de mediaan ligt op 1,71. Etnische distantie is dus rechts-scheef verdeeld. Dit betekent dat de meeste leerlingen slechts geringe etnische distantie hebben.

Om de kwaliteit van interetnisch contact te bepalen is leerlingen gevraagd hoe zij hun contact met Nederlanders, Surinamers, Antillianen, Turken, Marokkanen, en 'anderen' in de klas, op school, in de buurt, op sportverenigingen en op andere verenigingen ervaren. Het contact kon worden beoordeeld als heel negatief, negatief, neutraal, positief en heel positief. Wanneer leerlingen geen contact hadden met een bepaalde groep, konden ze dat kenbaar maken door middel van de antwoordmogelijkheid niet van toepassing. Aan de hand van de ervaren etniciteit is bepaald of een leerling in zijn of haar klas, school, buurt, sport- en vrijetijdsvereni- 
ging interetnisch contact had en of dit contact dan positief, neutraal of negatief was. Vanwege collineariteit is bij het bepalen van de kwaliteit van het contact geen onderscheid gemaakt tussen de contacten met de verschillende etnische groepen. De kwaliteit van interetnisch contact in een bepaalde setting is dus het gemiddelde van de beoordelingen van het contact met de verschillende etnische groepen in de betreffende setting.

Om vast te stellen in hoeverre het schoolbeleid de multiculturele samenleving ondersteunt is aan leerlingen gevraagd of er tijdens lessen nooit, zelden, soms of vaak gesproken wordt over racisme en discriminatie, en of er nooit, zelden, soms of vaak gesproken wordt over gewoonten en gebruiken van mensen uit andere landen. Het gemiddelde van deze twee vragen vormde de maatstaf voor de mate waarin een leerling ervaart dat er tijdens lessen aandacht wordt besteed aan de multiculturele samenleving. Leerlingen die één (1) scoorden op deze schaal, gaven te kennen dat er in lessen nooit aandacht wordt besteed aan de multiculturele samenleving, terwijl leerlingen die vier (4) scoorden, te kennen gaven dat er juist vaak aandacht wordt besteed aan discriminatie en andere culturen. De gemiddelde standaardafwijking van het klassengemiddelde van deze individuele perceptie is 0,069 en deze varieert tussen 0,027 en 0,141. Deze geringe spreiding binnen klassen toont aan dat de individuele metingen een behoorlijk betrouwbare indicatie geven voor de hoeveelheid aandacht die in de klas besteed wordt aan de multiculturele samenleving. De individuele scores zijn dan ook geaggregeerd naar het niveau van de klas en vormen daarmee het contextuele klassenkenmerk voor de mate waarin het schoolbeleid de multiculturele samenleving ondersteunt. Deze scores zijn bewust niet geaggregeerd naar het niveau van de school, omdat het aantal scholen, tien, te laag is om een betrouwbaar analyseniveau te vormen (Hox, 2002).

De etnische diversiteit van de klas is vastgesteld door middel van de Blau Index (Blau, 1977). De Blau Index geeft de kans weer dat twee willekeurig gekozen individuen uit een populatie van verschillende afkomst zijn. De Blau Index is als volgt geconstrueerd:

Etnische diversiteit $=1-\sum_{i=1}^{g} \mathrm{p}_{i}{ }^{2}$

Hierbij is de etnische diversiteit van de klas gebaseerd op de proportie leerlingen $p$ in de klas die tot de etnische groep $i$ behoren, waarbij $p_{i}^{2}$ gesommeerd is over alle verschillende etnische groepen $g$ in de klas. Wanneer er sprake is van een volledig homogene populatie is de Blau Index nul (o), en wanneer elk individu van een andere afkomst is - en het aantal etnische groepen groot is - benadert de Blau Index de score één (1). Aan de hand van de ervaren etniciteit is het percentage Nederlandse, Turkse, 
Marokkaanse, Caribische en 'overige' leerlingen in de klas bepaald. Op basis van deze percentages is vervolgens de Blau Index voor de etnische heterogeniteit in de klas berekend. Hoewel de Blau Index bekritiseerd wordt omdat deze slechts kijkt naar de etnische diversiteit van een populatie en daarmee geen rekening houdt met exacte etnische samenstelling3 (Rushton, 2007), is deze kritiek niet relevant voor deze studie omdat de hypothesen enkel betrekking hebben op etnische diversiteit en er niet gekeken wordt naar de invloed van exacte etnische compositie van de klas en buurt.

Door middel van de postcode van het thuisadres is het percentage autochtonen, westerse allochtonen en niet-westerse allochtonen in de buurt waar de leerling woont bij het CBS achterhaald. Aan de hand van deze drie percentages is de Blau Index voor de etnische diversiteit van de buurt berekend.

\section{Meetinstrumenten: controlevariabelen}

Xenofobe houdingen worden niet alleen verklaard door interetnisch contact. De ervaren culturele en sociaaleconomische dreiging, zelfwaardering, de waardering van de eigen etnische identiteit, religiositeit en de sterkte van etnische identificatie blijken ook van invloed te zijn op xenofobe houdingen (Dekker et al., 2007; Gijsberts \& Dagevos, 2005; Hello, 2003; Postma, 2007). Deze factoren zijn dan ook naast de gebruikelijke controlevariabelen, geslacht, leeftijd en doubleren, opgenomen in de analyses.

Om de ervaren culturele dreiging te bepalen bevatte de enquête een tiental stellingen over de multiculturele samenleving die in eerder onderzoek hun geldigheid en betrouwbaarheid hadden bewezen (zie ondermeer Prinsen \& Verkuyten, 2006; Verkuyten \& Thijs, 2002a). Deze stellingen staan weergegeven in Appendix A. De gezamenlijke factoranalyse laat echter zien dat het item In de samenleving moet geen enkele groep meer te zeggen hebben dan andere groepen niet hetzelfde meet als de overige items. Daarnaast toont de betrouwbaarheidsanalyse aan dat dit item een substantieel lagere inter-item correlatie heeft (o,3 lager) met de overige items. Dit item is dan ook niet gebruikt bij de constructie van de schaal voor ervaren culturele dreiging. De uiteindelijke schaal is geconstrueerd op basis van negen items en blijkt een betrouwbare schaal te vormen (Cronbachs alfa is 0,87 ). Een lage score op deze schaal betekent weinig ervaren culturele dreiging, een hoge score daarentegen betekent veel ervaren culturele dreiging.

Om de mate van de ervaren sociaaleconomische dreiging te bepalen zijn vijf stellingen voorgelegd over de toekomstige sociaaleconomische situatie. Leerlingen is gevraagd of ze denken in de toekomst werk te hebben, 
een goed betaalde baan te hebben, een huis te kunnen kopen, een betere baan te hebben dan hun ouder(s)/verzorger(s) en of ze een leuke baan zullen hebben. Het item ik krijg een betere baan dan mijn ouder(s)/verzorger(s) blijkt echter te refereren aan een andere dimensie en de inter-item correlatie van dit item met de overige items blijkt substantieel lager te zijn (o,2 lager). Om deze reden is dit item niet gebruikt bij de constructie van de schaal voor ervaren sociaaleconomische dreiging. De overige items vormen een betrouwbare schaal (Cronbachs alfa is o,84). Een lage score op deze schaal betekent dat een leerling een slechte sociaaleconomische toekomstsituatie verwacht en een hoge score duidt op de verwachting van een goede sociaaleconomische situatie in de toekomst.

De tien items van de Rosenberg-zelfwaarderingsschaal (Rosenberg, 1965) zijn gebruikt om de zelfwaardering van leerlingen te bepalen. De afzonderlijke items staan weergegeven in Appendix A. Deze items blijken een betrouwbare schaal te vormen (Cronbachs alfa is o,87). Een lage score op de Rosenberg-zelfwaarderingsschaal betekent een lage zelfwaardering en een hoge score betekent een hoge zelfwaardering.

Om de waardering van de etnische identiteit te bepalen zijn de vier items van de 'private collectieve zelfwaarderingschaal' van Luhtanen en Crocker (1992) aan de leerlingen voorgelegd. De collectieve zelfwaardering is de tevredenheid met het behoren tot een bepaalde (etnische) groep. De 'private collectieve zelfwaarderingschaal' meet hiervan een aspect, namelijk de ervaren maatschappelijke positie en waardering van de eigen groep. De items Ik zou liever van een andere afkomst zijn en Mensen van mijn afkomst worden vaak benadeeld blijken in een factoranalyse te lage communaliteiten te hebben $(0,13$ respectievelijk o,02) om ze op te nemen in de schaal. Tevens blijken deze items de betrouwbaarheidscoëfficiënt te verlagen met 0,16 respectievelijk 0,07. Deze items zijn dan ook niet gebruikt bij het construeren van de collectieve zelfwaarderingsschaal. De overige twee items, Over het algemeen ben ik trots op mijn afkomst en $I k$ heb een goed gevoel bij mijn afkomst, blijken betrekking te hebben op één dimensie en zijn tevens redelijk goed schaalbaar (Cronbachs alfa is 0,75 ). Een lage score op deze schaal betekent een lage collectieve zelfwaardering, terwijl een hoge score staat voor een hoge collectieve zelfwaardering.

Om de religiositeit van leerlingen te bepalen is allereerst gevraagd of leerlingen zich al dan niet als lid van een geloofsgemeenschap beschouwen. Leerlingen die zichzelf niet als lid van een geloofsgemeenschap beschouwen, worden als niet religieus beschouwd. Aan religieuze leerlingen is vervolgens gevraagd of zij nooit, jaarlijks, maandelijks, of wekelijks diensten of bijeenkomsten van hun religie bezoeken. Deze maat voor religieuze participatie is gebruikt als indicator voor de mate van religiositeit onder religieuze leerlingen. 
De sterkte van de etnische identificatie is gemeten met behulp van dezelfde items die de etniciteit bepalen. Voor de bepaling van de sterkte van de etnische identificatie voor leerlingen die zichzelf tot één etniciteit rekenen of die zich sterker tot één bepaalde etniciteit rekenen is gebruikgemaakt van de mate waarin deze leerlingen zich tot de betreffende etniciteit rekenen. De schaal loopt van één (1),,helemaal niet, tot vijf (5), de score voor leerlingen die zich heel sterk tot een etniciteit rekenen. Leerlingen die zich met gelijke sterkte tot twee etniciteiten rekenen, dit waren overigens maar zes leerlingen, krijgen de score één (1) op de schaal van de sterkte van etnische identificatie, omdat zij zich niet sterk tot één etniciteit rekenen.

Tot slot is ook gevraagd of leerlingen al of niet één of meerdere keren zijn blijven zitten op de middelbare school, wat hun leeftijd is en of ze een jongen of een meisje zijn.

Tabel 1 toont het gemiddelde, de standaarddeviatie, het minimum en het maximum van alle hierboven beschreven variabelen.

\section{Methode}

De data die in deze studie zijn gebruikt, kenmerken zich door een niethiërarchische multiniveaustructuur. Leerlingen (niveau 1) zijn zowel genest in klassen (niveau 2) en scholen (niveau 3), als in buurten (niveau 2). Leerlingen uit dezelfde buurt gaan echter niet vanzelfsprekend naar dezelfde school, laat staan dat ze in dezelfde klas zitten. Om de etnische distantie van leerlingen te verklaren door individuele en contextuele kenmerken is lineaire niet-hiërarchische multiniveauanalyse dan ook noodzakelijk. Ook al kennen de data drie niveaus, het schoolniveau (niveau 3) wordt buiten beschouwing gelaten omdat het aantal scholen, tien, te laag is voor betrouwbare multiniveauanalyses (Hox, 2002). De basis vergelijking voor het niet-hiërarchische tweeniveaumodel (met klassen en buurten) ziet er als volgt uit:

$\mathrm{y}_{\mathrm{i}(\mathrm{k}, \mathrm{b})}=\beta_{\mathrm{o}}+\delta_{\mathrm{k}}+\delta_{\mathrm{b}}+\mathrm{e}_{1(\mathrm{k}, \mathrm{b})}$

waarbij $\beta_{o}$ de gemiddelde etnische distantie is van alle leerlingen, $k$ en $b$ staan voor respectievelijk klas en buurt, $\delta_{\mathrm{k}}$ het random effect is van klas, $\delta_{\mathrm{b}}$ het random effect is van buurt, $\mathrm{y}_{\mathrm{i}(\mathrm{k}, \mathrm{b})}$ de etnische distantie is van leerling $i$ in klas $\mathrm{k}$ en buurt $b$, en $\mathrm{e}_{1(\mathrm{k}, \mathrm{b})}$ de afwijking is van de etnische distantie van leerling $i$ tot de gemiddelde distantie van de combinatie klas $k$ en buurt $b$.

Hoewel de vragenlijsten klassikaal en onder het toezicht van een docent waren afgenomen, zijn in sommige gevallen niet alle vragen 
Tabel 1 Beschrijving van de gebruikte variabelen

\begin{tabular}{|c|c|c|c|c|}
\hline Variabele & Gemiddelde & Std. deviatie & Minimum & Maximum \\
\hline Etnische distantie & 1.890 & 0,800 & I & 5 \\
\hline Etniciteit: Nederlandse & 0,782 & & 0 & I \\
\hline Etniciteit:Turkse & 0,037 & & 0 & I \\
\hline Etniciteit: Marokkaanse & 0,026 & & 0 & I \\
\hline Etniciteit: Caribische & 0,030 & & 0 & I \\
\hline Etniciteit: anders & 0,108 & & 0 & I \\
\hline Geen contact klas & 0,284 & & 0 & I \\
\hline Negatief contact klas & 0,057 & & 0 & I \\
\hline Neutraal contact klas & 0,125 & & 0 & I \\
\hline Positief contact klas & 0,535 & & 0 & I \\
\hline Geen contact school & 0,335 & & 0 & I \\
\hline Negatief contact school & 0,059 & & 0 & I \\
\hline Neutraal contact school & 0,075 & & 0 & I \\
\hline Positief contact school & 0,530 & & 0 & I \\
\hline Geen contact sportvereniging & 0,607 & & 0 & I \\
\hline Negatief contact sportvereniging & 0,024 & & 0 & I \\
\hline Neutraal contact sportvereniging & 0,046 & & 0 & I \\
\hline Positief contact sportvereniging & 0,323 & & 0 & 1 \\
\hline Geen contact overige vereniging & 0,919 & & 0 & I \\
\hline Negatief contact overige vereniging & 0,006 & & 0 & I \\
\hline Neutraal contact overige vereniging & 0,004 & & 0 & I \\
\hline Positief contact overige vereniging & 0,071 & & 0 & I \\
\hline Geen contact buurt & 0,399 & & 0 & I \\
\hline Negatief contact buurt & 0,084 & & 0 & I \\
\hline Neutraal contact buurt & 0,127 & & 0 & I \\
\hline Positief contact buurt & 0,390 & & 0 & I \\
\hline Culturele dreiging & 2.833 & 0,779 & I & 5 \\
\hline Sociaal-economische-dreiging & 5.764 & $0,94 I$ & I & 7 \\
\hline Zelfwaardering & 3.095 & 0,483 & I & 4 \\
\hline Waardering etnische afkomst & 6.001 & 1.134 & I & 7 \\
\hline Sterkte etnische identificatie & 4.374 & 0,927 & I & 5 \\
\hline Kerkgang: wekelijks & 0,029 & & 0 & I \\
\hline Kerkgang: maandelijks & 0,030 & & 0 & I \\
\hline Kerkgang: jaarlijks & 0,143 & & 0 & 1 \\
\hline Kerkgang: nooit & 0,070 & & 0 & I \\
\hline Kerkgang: niet religieus & 0,720 & & 0 & I \\
\hline VMBO basis & 0,186 & & 0 & I \\
\hline VMBO theoretisch & 0,219 & & 0 & I \\
\hline HAVO & 0,377 & & 0 & I \\
\hline VWO & 0,218 & & 0 & I \\
\hline Sekse, jongen is I & 0,519 & & 0 & I \\
\hline Leeftijd & 16.349 & 0,669 & 15 & 19 \\
\hline Blijven zitten & 0,132 & & 0 & 1 \\
\hline Heterogeniteit klas ${ }^{a}$ & 0,319 & 0,162 & 0 & 0,710 \\
\hline Heterogeniteit buurt ${ }^{b}$ & 0,304 & 0,109 & 0,066 & 0,528 \\
\hline Aandacht multiculturele samenleving ${ }^{a}$ & 2.532 & 0,224 & 1.643 & 3.065 \\
\hline
\end{tabular}

$n=1.444$ leerlingen

${ }^{a}$ aantal klassen $=77$

${ }^{b}$ aantal buurten $=117$

Bron: Scholieren over zichzelf en elkaar, 2007 
ingevuld. 261 leerlingen $(18,1 \%)$ hebben één of meerdere vragen niet ingevuld, waarbij deze 261 leerlingen gelijkmatig verdeeld blijken te zijn over verschillende klassen. Multipele imputatie volgens de procedure van Rubin (1987) is gebruikt om de ontbrekende gegevens bij te schatten. Rekeninghoudend met de verschillende niveaus van de data (door in de imputatieprocedure afzonderlijke dummies op te nemen voor de verschillende klassen en buurten), zijn de ontbrekende gegevens vijfmaal vervangen door Markov Chain Monte Carlo-schattingen (MCMC) op basis van alle beschikbare informatie in het databestand. Hiervoor is gebruikgemaakt van de 'MI'-procedure in het computerprogramma SAS 9.1. Vervolgens zijn de vijf resulterende volledige datasets geanalyseerd, waarna de resultaten gecombineerd zijn met de 'MIANALYZE'-procedure in SAS 9.1. De gegevens van alle 1444 leerlingen konden hierdoor gebruikt worden bij de constructie van de meetinstrumenten en de analyses.

Tabel 2 geeft de resultaten weer van de niet-hiërarchische multiniveauanalyses van de etnische distantie van leerlingen. De intervalvariabelen zijn gecentreerd op het gemiddelde om de interpretatie van de parameters te vergemakkelijken. In alle modellen is nagegaan of er sprake was van collineariteit tussen de verschillende variabelen. Dit heeft ertoe geleid dat de kwaliteit van contact op vrijetijdsverenigingen niet is opgenomen in de analyses omdat deze collineair bleek te zijn met de kwaliteit van contact op sportverenigingen. Verder is er gecontroleerd of er sprake is van een lineaire samenhang tussen de afhankelijke variabele etnische distantie en de verklarende continue variabelen. Uit deze controle kwam naar voren dat etnische distantie niet lineair afhankelijk is van kerkgang. Kerkgang is om die reden dan ook als categorische variabele opgenomen in de analyses. Tevens is nagegaan of in de analyses wordt voldaan aan de belangrijkste assumpties van de lineaire niet-hiërarchische multiniveauanalyse. Er is nagegaan of: het gemiddelde van de residuen voor elke waarde van $\mathrm{X}$ nul is $\left(E\left(\mathrm{e}_{\mathrm{i}} \mid \mathrm{X}_{\mathrm{i}}\right)=0\right)$; de residuen ongecorreleerd zijn $\left(E\left(e_{i} e_{j}\right)=0\right)$; de residuen voor elke waarde van $X$ dezelfde variantie hebben $\left(\operatorname{var}\left(\mathrm{e}_{\mathrm{i}} \mid \mathrm{X}_{\mathrm{i}}\right)=\sigma^{2}\right)$. Deze assumpties bleken niet geschonden te worden. Derhalve blijkt de analysemethode geschikt te zijn om de etnische distantie van jongeren te verklaren ondanks de rechts-scheve verdeling van de afhankelijke variabele. Ten slotte zijn bij de bepaling van de significantie de $p$-waarden gecorrigeerd met de 'falsediscoveryrate' (Benjamini \& Hochberg, 1995) om de kans op type-I fouten, het ten onrechte bevestigen van een hypothese, tot een minimum te beperken. De kans op type-I fouten is in deze studie namelijk aanzienlijk gezien het grote aantal te schatten parameters. 


\section{Analyses en resultaten}

Model 1 is een leeg model met enkel een constante en variantiecomponenten binnen en tussen klassen en buurten. Uit dit model komt naar voren dat de gemiddelde etnische distantie van de 1444 leerlingen 0,070 bedraagt op de gecentreerde schaal, die loopt van -0,892 tot 3,111. Van de totale variantie in etnische distantie kan $\left[\left(\left(0,145 /\left(0,145^{\left.\left.\left.+0,024^{+0}, 509\right)\right)^{*} 100\right]}\right.\right.\right.\right.$ $21,4 \%$ toegeschreven worden aan verschillen tussen klassen, 3,6\% aan verschillen tussen buurten en $75,0 \%$ aan verschillen tussen leerlingen.

Om de hypothesen omtrent de etnische diversiteit van de klas en buurt te toetsen wordt in model 2 de etnische heterogeniteit van de klas en de buurt toegevoegd. De etnische heterogeniteit van de buurt blijkt significant negatief samen te hangen met de etnische distantie van leerlingen. Leerlingen die in etnisch meer heterogene buurten wonen hebben, zoals verwacht in hypothese 2 , minder etnische distantie dan leerlingen die in etnisch minder heterogene buurten wonen. De etnische heterogeniteit van de klas blijkt niet significant samen te hangen met de etnische distantie van leerlingen. De hypothese dat leerlingen in een meer etnisch diverse klas minder etnische distantie hebben (hypothese 1) wordt dus niet bevestigd.

In model 3 worden de individuele controlekenmerken toegevoegd. Hiermee kunnen we nagaan in hoeverre verschillen en invloeden op het niveau van de klas en de buurt toe te schrijven zijn aan compositie-effecten. Het toevoegen van de individuele controlekenmerken doet het significante effect van de etnische heterogeniteit van de buurt verdwijnen. Tevens is de variantie op het niveau van de buurt niet langer significant. Dit betekent dat verschillen tussen buurten in de mate van etnische distantie verklaard worden door verschillen in de samenstelling van buurten met betrekking tot de individuele significante kenmerken in model 3. Oftewel, het zijn niet de verschillen tussen buurten, maar verschillen in de kenmerken van de jongeren die in die buurten wonen die er voor zorgen dat de gemiddelde etnische distantie tussen buurten verschilt. Verder blijkt uit model 3 dat de etnische distantie afneemt naarmate leerlingen een hoger opleidingsniveau volgen. Daarnaast blijkt dat niet religieuze leerlingen minder etnische distantie hebben dan religieuze leerlingen die wekelijks naar (kerk)diensten gaan. Verder blijkt dat leerlingen die zichzelf als Turks of Marokkaans beschouwen meer etnische distantie hebben dan leerlingen die zichzelf als Nederlander zien. Voorts hebben leerlingen die zich sterker identificeren met hun etniciteit meer etnische distantie. Ook blijken leerlingen die meer culturele dreiging ervaren en leerlingen die meer collectieve zelfwaardering hebben meer etnische distantie te hebben. Ten slotte blijken jongens meer etnische distantie te hebben dan meisjes. De invloed van deze significante controlevariabelen komt overeen met resultaten uit eerdere onderzoeken (Dek- 
ker et al., 2007; Gijsberts \& Dagevos, 2005; Hello, 2003; Postma, 2007).

Om de hypothesen omtrent interetnisch contact te toetsen is in model 4 de kwaliteit van het interetnisch contact in de klas, op school, op sportverenigingen en in de buurt toegevoegd. Deze toevoeging leidt ertoe dat de variantie op het klassenniveau niet langer significant is. Verschillen tussen klassen kunnen dus volledig verklaard worden door middel van de significante individuele kenmerken in model 4. Het zijn dus geen klassenkenmerken maar verschillen in de kenmerken en contactervaringen van individuele leerlingen die ervoor zorgen dat de gemiddelde etnische distantie tussen klassen verschilt.

Ook na controle voor de kwaliteit van interetnische contacten blijken leerlingen die zichzelf als Turks of Marokkaans beschouwen meer etnische distantie te hebben dan leerlingen die zichzelf als (autochtone) Nederlander beschouwen. Overigens blijkt dat na toevoeging van deze contactvariabelen ook leerlingen die zichzelf tot een 'andere' etniciteit rekenen, significant meer etnische distantie hebben dan leerlingen die zichzelf als Nederlander beschouwen.

De kwaliteit van interetnisch contact in de klas blijkt significant gerelateerd te zijn aan etnische distantie zoals verondersteld in de hypothesen za en 4a. Leerlingen die negatief interetnisch contact in hun klas hebben, hebben meer etnische distantie dan leerlingen die neutraal contact hebben. Daarentegen hebben leerlingen die positief interetnisch contact hebben minder etnische distantie dan leerlingen die neutraal contact hebben. Tegen de verwachting van hypothese 5 in is negatief contact in de klas niet significant sterker gerelateerd aan etnische distantie dan positief contact. Het verschil in effectgrootte blijkt namelijk niet significant: $t(0)=0,22, p>0,1$. Opmerkelijk is dat leerlingen die geen interetnisch contact hebben minder etnische distantie hebben dan leerlingen die neutraal contact hebben.

Als we vervolgens kijken naar interetnisch contact op de school, dan blijkt - in tegenstelling tot contact in de klas - alleen positief interetnisch contact een significante relatie te hebben met de etnische distantie van leerlingen. Leerlingen met positief contact op school hebben, in overeenstemming met hypothese $3 \mathrm{~b}$, minder etnische distantie dan leerlingen die neutraal interetnisch contact op hun school hebben. Positief interetnisch contact in de buurt heeft daarentegen geen invloed op de etnische distantie van leerlingen. Alleen negatief interetnisch contact in de buurt is gerelateerd aan de etnische distantie van leerlingen. Leerlingen met negatief contact in hun buurt hebben, in overeenstemming met hypothese $4 \mathrm{c}$, meer etnische distantie dan leerlingen met neutraal interetnisch contact in hun buurt. In tegenstelling tot onze verwachtingen blijkt geen enkele vorm van interetnisch contact op sportverenigingen de etnische distantie te beïnvloeden. 
90

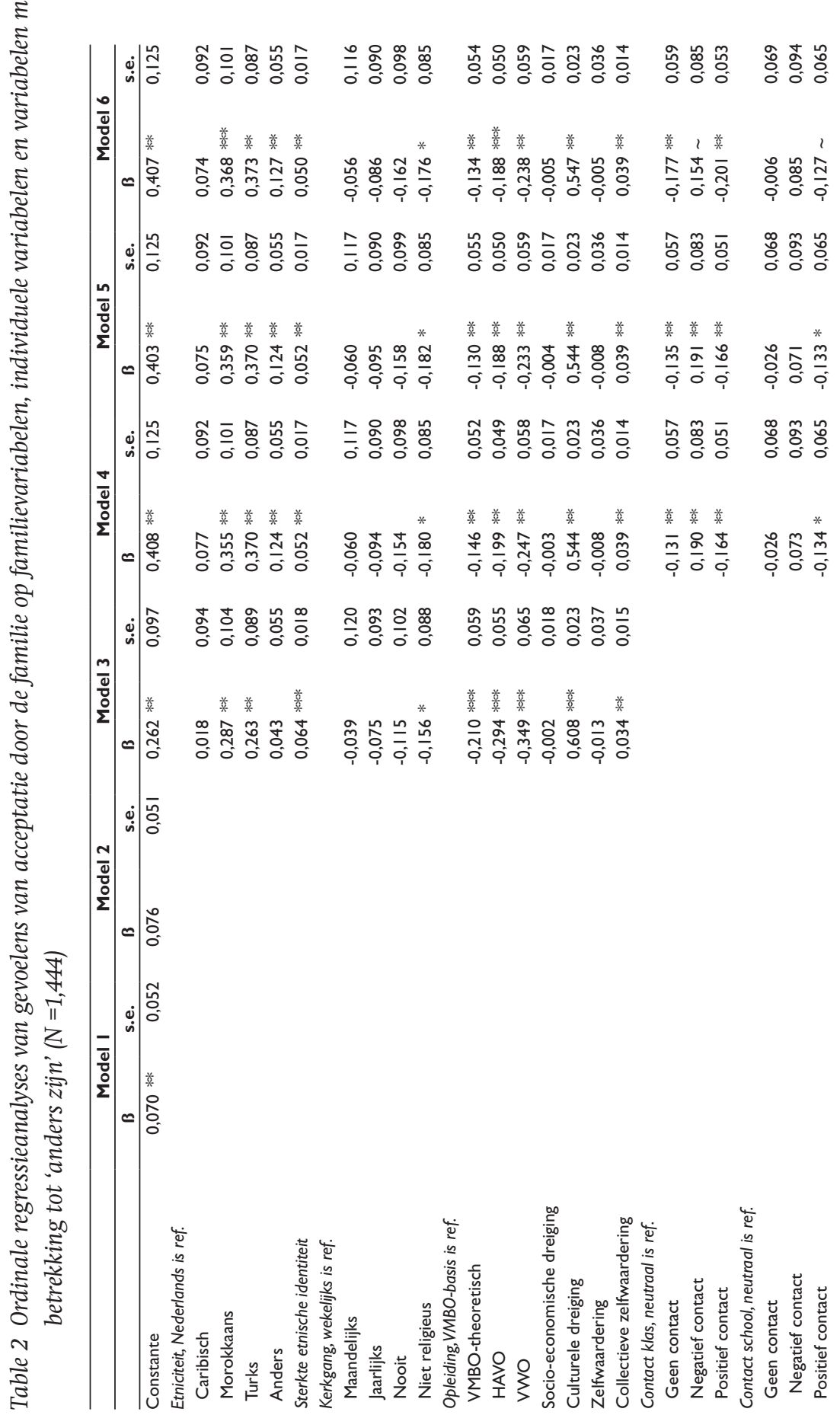




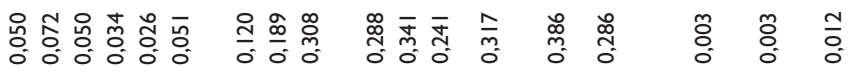

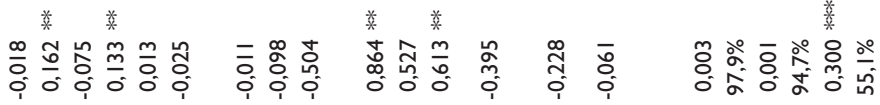

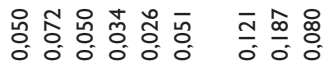

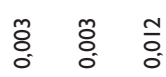

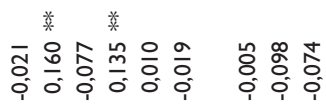

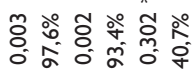

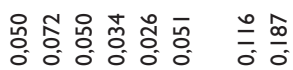

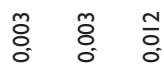

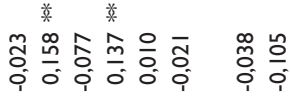

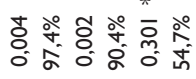

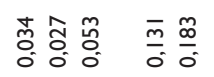

芒管

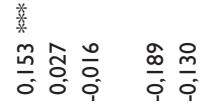

*

占 :

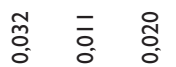

虽

葲,

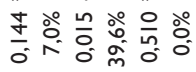

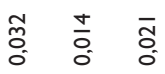

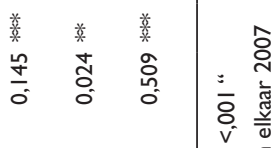

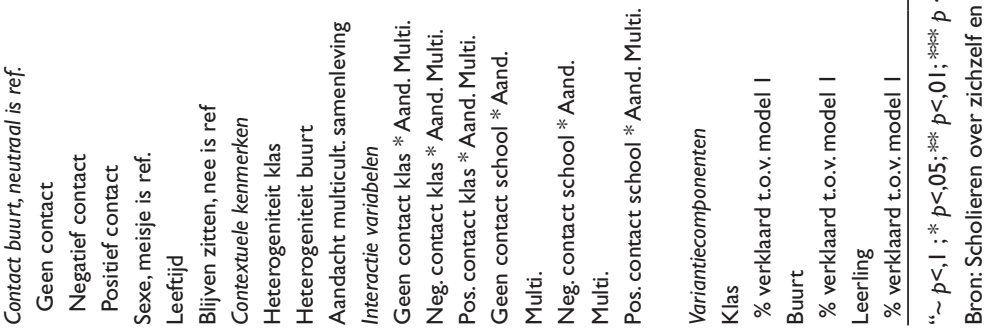


Van alle onderzochte contactsituaties (in de klas, op school, in de buurt of op sportverenigingen) blijkt alleen in de klas te gelden dat zowel positief als negatief interetnisch contact verbonden zijn met de mate van etnische distantie van leerlingen. Dit lijkt erop te duiden dat contact in de klas belangrijker is dan contact op school, in de buurt en op sportverenigingen (hypothese 9). Het blijkt echter niet zo te zijn dat de gevonden verbanden voor interetnisch contact in de klas systematisch groter zijn dan de verbanden voor interetnisch contact in andere situaties. Uit de toets op het verschil in effectgrootte komt namelijk naar voren dat het effect van positief contact in de klas niet significant groter is dan het effect van positief contact op school $[t(0)=-0,33, p>0,1]$. Ook het effect van negatief contact in de klas blijkt niet significant groter te zijn dan het effect van negatief contact in de buurt $[t(0)=0,28, p>0,1]$. De hypothese dat interetnisch contact in de klas belangrijker is dan contacten op school, in de buurt en op vrijetijdsverenigingen (hypothese 9) wordt dus niet bevestigd.

Om na te gaan wat de invloed is van de mate waarin klassikaal aandacht wordt besteed aan de multiculturele samenleving is in model 5 deze variabele toegevoegd. Er blijkt geen significante invloed uit te gaan van de mate waarin klassikaal aandacht wordt besteed aan de multiculturele samenleving. Uiteindelijk blijkt dit model zonder interactietermen $97,6 \%$ van de variantie tussen klassen, 93,4\% van de variantie tussen buurten en $41,1 \%$ van de variantie tussen leerlingen te kunnen verklaren.

In model 6 zijn ten slotte interactie-effecten opgenomen om de verwachte relatie tussen het schoolbeleid en positief of negatief contact in de klas en op school te toetsen. De interactie-effecten tussen de kwaliteit van interetnisch contact op school en de aandacht die besteed wordt aan de multiculturele samenleving blijken niet significant te zijn. Hypothesen $7 \mathrm{~b}$ en $8 \mathrm{~b}$ worden dus niet bevestigd. Ook hypothese $8 \mathrm{a}$ wordt weerlegd omdat het effect van negatief contact in de klas niet varieert met de mate waarin in de klas aandacht aan de multiculturele samenleving wordt besteed. De interactie-effecten tussen geen dan wel positief contact in de klas en de aandacht die besteed wordt aan de multiculturele samenleving zijn echter wel significant. Naarmate er meer aandacht wordt besteed aan de multiculturele samenleving, wordt het verband tussen de mate van etnische distantie en positief of geen interetnisch contact in de klas minder sterk negatief. Dus terwijl gemiddeld genomen leerlingen met positief interetnisch contact in de klas minder etnische distantie hebben, blijkt dit verband minder sterk te zijn indien er volgens leerlingen in de klas relatief vaker aandacht wordt besteed aan de multiculturele samenleving. Tevens blijkt dat wanneer er relatief veel aandacht wordt besteed aan de multiculturele samenleving in de 
klas, het ontbreken van interetnisch contact tussen klasgenoten eerder gepaard gaat met meer etnische distantie. In figuur 1 zijn deze interactie-effecten grafisch weergegeven. Figuur 1 laat de geobserveerde etnische distantie zien van de gemiddelde leerling die geen of positief interetnisch contact in de klas heeft ten opzichte van de gemiddelde leerling met neutraal contact in de klas. Dit verband tussen contact en etnische distantie varieert naar de mate waarin er aandacht wordt besteed aan de multiculturele samenleving. In figuur 1 is de mate waarin volgens de leerlingen in de klas aandacht wordt besteed aan de multiculturele samenleving verdeeld in 5 categorieën: (namelijk minimaal gerapporteerde aandacht aan de multiculturele samenleving; 1 standaard deviatie onder het gemiddelde, gemiddelde aandacht, 1 standaard deviatie boven het gemiddelde en maximaal gerapporteerde aandacht). Duidelijk te zien is dat naarmate er meer aandacht wordt besteed aan de multiculturele samenleving, de etnische distantie toeneemt bij zowel de gemiddelde leerling met geen interetnisch contact in de klas als bij de gemiddelde leerling met positief interetnisch contact in de klas. Dit staat haaks op onze verwachting zoals verwoord in hypothese $7 \mathrm{a}$.

Figuur 1 Geobserveerd verschil in etnische distantie van leerlingen met positief of geen interetnisch contact in de klas ten opzichte van leerlingen met neutraal contact, uitgesplitst naar de mate waarin in de klas aandacht wordt besteed aan de multiculturele samenleving

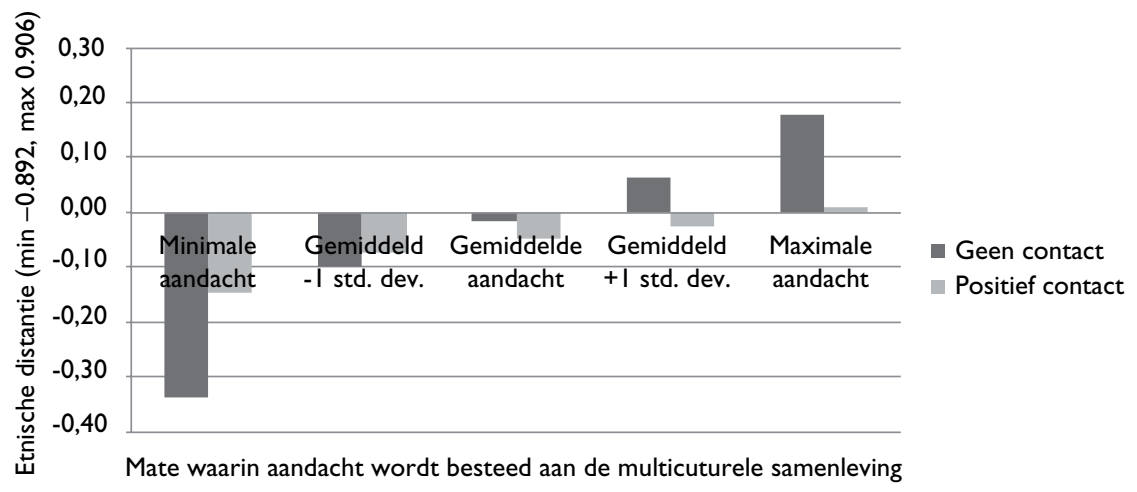

Ten slotte hebben we in een aanvullend model interactie-effecten opgenomen om de verwachting te toetsen dat negatief interetnisch contact in een bepaalde situatie de invloed van positief contact in een andere situatie verkleint. Geen van deze interactie-effecten bleek echter significant te zijn, waardoor we ervoor gekozen hebben dit model niet af te beelden. Het resultaat weerspreekt daarmee hypothese 6 . 


\section{Conclusie en discussie}

In deze studie is op drie manieren vooruitgang geboekt bij het in beeld brengen en verklaren van xenofobe houdingen van jongeren. Allereerst heeft deze studie zich gericht op de houding van zowel autochtone als allochtone jongeren. Daarnaast hebben we gekeken naar wat de invloed van zowel positief als negatief interetnisch contact in verschillende contactsituaties is. En ten slotte hebben we onder andere gecontroleerd voor opleidingsniveau, persoonlijkheid en ervaren culturele- en sociaaleconomische dreiging. De vraag die in deze studie centraal stond, luidde dan ook: In welke mate hebben middelbare scholieren op verschillende opleidingsniveaus en met verschillende etnische achtergronden een xenofobe attitude? En in hoeverre bestaat er een samenhang tussen deze attitude en positief en negatief interetnisch contact in de klas, op school, bij vrijetijdsverenigingen, en in de buurt?

Niet-hiërarchische multiniveauanalyses onder 1444 jongeren uit de vierde klas van middelbare scholen in Nijmegen en omgeving toonden allereerst dat de meeste jongeren een geringe xenofobe houding hebben. Vervolgens bleek de xenofobe houding van jongeren, zoals verwacht, te worden beïnvloed door het interetnische contact dat jongeren hebben. Alhoewel het hebben van de mogelijkheid tot interetnisch contact van cruciaal belang is, is het met name de kwaliteit van het contact dat de houding van jongeren beïnvloedt en niet zozeer de kwantiteit ervan. Dit is gebleken uit de bevinding dat de etnische diversiteit van klassen en buurten niet van invloed zijn op de etnische distantie. Ook het gegeven dat het ontbreken van interetnisch contact - in vergelijking met neutraal ervaren interetnisch contact - niet gepaard gaat met meer etnische distantie, en in het geval van contact in de klas zelfs gepaard gaat met minder etnische distantie, impliceert het belang van de kwaliteit boven kwantiteit.

Doordat we in deze studie geen gebruik hebben kunnen maken van een longitudinaal design, hebben we de causale relatie tussen interetnisch contact en etnische distantie niet vast kunnen stellen. Het is mogelijk dat de causale relatie tussen interetnisch contact en een xenofobe houding ook in tegenovergestelde richting loopt. Twee zaken doen vermoeden dat een mogelijke vertekening van onze bevindingen door het causaliteitsprobleem slechts gering zal zijn. Ten eerste hebben we gekeken naar gedwongen interetnisch contact, het contact in de klas. Etnische voorkeuren kunnen bij gedwongen etnische contacten in principe geen rol spelen. De vraag is echter wel in hoeverre de etnische samenstelling van de klas, en dus de mogelijkheid tot het hebben van gedwongen interetnisch contact, indirect beïnvloed is door de etnische voorkeuren van de ouders.

Ten tweede blijkt geen enkele vorm van interetnisch contact op sport- 
verenigingen van invloed te zijn op de houding van leerlingen. Contact op sportverenigingen werd verondersteld het meest beïnvloed te zijn door de houding ten aanzien van andere etnische groepen. Nu blijkt dat interetnisch contact op sportverenigingen niet samenhangt met de xenofobe houding van leerlingen, betekent dit in wezen ook dat deze houding niet van invloed is op het hebben van en de beoordeling van interetnische contacten op sportverenigingen. Ook bij dit argument dienen we echter een kanttekening te plaatsen. Nederlandse sportverenigingen blijken immers etnisch behoorlijk homogeen te zijn (Van der Meulen \& Ultee, 2006). Het is dan ook maar de vraag of het ontbreken van een significant verband tussen de kwaliteit van het contact op sportverenigingen en de xenofobe houding komt doordat er daadwerkelijk geen causale relatie is. Een alternatieve verklaring voor het uitblijven van een significante relatie zou zijn dat leerlingen in onze dataset nauwelijks naar etnisch heterogene sportclubs gaan.

De analyse van gedwongen interetnische contacten, en het feit dat de kwaliteit van interetnische contacten op sportverenigingen niet van invloed is op de xenofobe houding van leerlingen doen dus vermoeden dat vertekeningen als gevolg van het causaliteitsprobleem gering zijn. De hierboven gemaakte kanttekeningen maken echter het gebruik van een longitudinaal design toch noodzakelijk om het causaliteitsprobleem daadwerkelijk het hoofd te bieden.

In deze studie vonden we zowel voor positief als negatief ervaren contact in de klas de verwachte relatie met etnische distantie. Leerlingen met positief interetnisch contact in de klas blijken namelijk een geringere etnische distantie te hebben en leerlingen met negatief interetnisch contact hebben een grotere etnische distantie. Beide vormen van contact blijken tegen de verwachting een even sterke relatie met etnische distantie te hebben. Op het niveau van de school blijken echter alleen positieve contacten van belang te zijn. Leerlingen die interetnisch contact op school als positief ervaren hebben een geringere etnische distantie dan leerlingen die dit contact als neutraal bestempelen. Het verband tussen positief contact op school en etnische distantie is even sterk als dat van positief contact in de klas en etnische distantie. Bij interetnische contacten in de buurt blijken alleen negatief ervaren contacten van belang te zijn. Leerlingen met negatief interetnisch contact in de buurt hebben een grotere etnische distantie. De relatie tussen etnische distantie en negatief contact in de buurt is even sterk als de relatie met negatief contact in de klas.

Volgens Allport (1954) zouden alleen positieve contacten die uit kunnen groeien tot vriendschappen, zoals 'duurzame' en 'nabije' contacten met klas- en schoolgenoten, vooroordelen kunnen verminderen en houdingen doen verbeteren. Daarentegen zouden contacten die deze 
potentie tot vriendschap niet hebben, zoals 'vluchtige' en 'afstandelijke' contacten met buurtgenoten, slechts leiden tot bevestiging van vooroordelen en het ontwikkelen van negatieve attituden (Allport, 1954; Pettigrew, 1998). Als Allports redenering op zou gaan, zouden positieve contacten in de klas de meeste invloed moeten hebben en zouden negatieve contacten in de buurt invloedrijker moeten zijn dan negatieve contacten in de klas. In onze studie vinden we hiervoor geen ondersteuning. Immers, in de klas zijn zowel positieve als negatieve contacten even sterk van belang. Daarnaast blijkt de invloed van interetnische contacten op sportverenigingen volledig afwezig te zijn en is de invloed van positief contact op school en van negatief contact in de buurt even sterk als de invloed van positief en negatief contact in de klas. Klaarblijkelijk zijn er naast de afstand tot het contact nog andere mechanismen die bepalend zijn voor de mate waarin de xenofobe houding beïnvloed wordt door negatief of positief contact. Te denken valt aan de invloed van de attitudes van vrienden of ouders, en aan de invloed van het metabeeld (het idee hoe anderen etnische groepen over de eigen etnische groep denken). In hoeverre het metabeeld en houdingen van naasten bepalend zijn voor de invloed van positief en negatief contact zal moeten blijken uit toekomstig onderzoek.

Het klassikaal stilstaan bij discriminatie en gewoonten en gebruiken van verschillende culturen beïnvloedt de xenofobe houding van jongeren niet direct, maar indirect. Naarmate er in de klas meer aandacht wordt besteed aan de multiculturele samenleving blijkt het verkleinende effect van zowel positief als geen interetnisch contact in de klas op de xenofobe houding minder sterk te zijn. Het klassikaal aandacht besteden aan verschillende culturen en het pleiten voor verdraagzaamheid heeft dus een tegenovergesteld effect dan verwacht. Deze bevinding is echter wel in overeenstemming met de resultaten van het onderzoek van Sniderman en Hagendoorn (2007) naar de invloed van het door de overheid bevorderen van de multiculturele samenleving volgens het 'top-down'principe. Sniderman en Hagendoorn laten zien dat wanneer er, op een positieve manier, publiekelijk aandacht wordt besteed aan multiculturalisme en minderheden, dit bij zowel de minst als de meest tolerante personen diepgelegen en in eerste instantie onuitgesproken gevoelens van wantrouwen ten aanzien van minderheden oproept (Sniderman \& Hagendoorn, 2007: 122). Een andere verklaring voor deze onverwachte bevinding is dat juist in klassen en op scholen waar problemen zijn tussen verschillende etnische groepen, aandacht wordt besteed aan de multiculturele samenleving. Deze redenering blijkt echter niet op te gaan. Het verband tussen de mate van aandacht aan de multiculturele samenleving en de mate waarin het contact in klassen negatief is, is namelijk niet significant $[r=-0,021, p>0,1]$. Het verband tussen de mate van 
aandacht aan de multiculturele samenleving en de mate van negatief contact op school is significant $[r=-0,107, p<0,1]$, maar op scholen waar minder negatieve contacten zijn, blijkt juist meer aandacht te worden besteed aan de multiculturele samenleving.

Tot slot is er ook een meer methodologische verklaring mogelijk. Aandacht besteden aan de multiculturele samenleving is namelijk gemeten door middel van de vragen hoe vaak er tijdens lessen wordt gesproken over racisme en discriminatie, en hoe vaak er gesproken wordt over gewoonten en gebruiken van mensen uit andere landen. Het bespreken van deze onderwerpen werd verondersteld een positieve stimulans te bieden om interetnische contacten aan te gaan. Wanneer echter negatieve gewoonten en gebruiken van andere culturen worden besproken, zoals eerwraak en vrouwenbesnijdenis, kan dit moeilijk worden beschouwd als een aanmoediging om interetnische contacten aan te gaan. Ook wanneer discriminatie slechts vanuit een eenzijdig 'daderslachtoffer'-perspectief wordt behandeld, kan dit moeilijk gezien worden als een stimulering van interetnisch contact. Vervolgonderzoek naar de inhoud van het multiculturele onderwijs is dan ook noodzakelijk voordat er geconcludeerd kan worden dat het klassikaal aandacht besteden aan de multiculturele samenleving daadwerkelijk een averechts effect heeft. Het is echter zondermeer duidelijk geworden dat het idee dat elke vorm van aandacht aan de multiculturele samenleving bijdraagt aan een tolerantere samenleving, niet blijkt te kloppen. Gezien de bevindingen van deze studie en de bevindingen van Sniderman en Hagendoorn is dan ook enige terughoudendheid geboden om de houding van leerlingen ten opzichte van andere etnische groepen te verbeteren door het onderwijscurriculum. In plaats van tijdens de lessen stil te staan bij de multiculturele samenleving en de verschillende aspecten hiervan, kan wellicht beter worden ingezet op het stimuleren van de mogelijkheden dat leerlingen van verschillende etnische komaf op een positieve manier met elkaar in aanraking komen.

\section{Noten}

1. Hidde Bekhuis en Marcel Coenders zijn als respectievelijk junior onderzoek en universitair hoofddocent verbonden aan de afdeling Algemene Sociale Wetenschappen van de Universiteit Utrecht. Stijn Ruiter is als universitair docent verbonden aan de afdeling Sociologie van de Radboud Universiteit Nijmegen. Adres voor correspondentie: Hidde Bekhuis, Afdeling Algemene Sociale Wetenschappen, Universiteit Utrecht, Postbus 80140, 3508 TC Utrecht. E-mail: h.bekhuis@ uu.nl.

2. Het meten van etniciteit door middel van de eigen perceptie heeft een aantal voordelen ten opzichte van het gebruik van de gangbare definitie van het Centraal Bureau voor de Statistiek (CBS), die de etniciteit bepaalt aan de hand van 
de herkomst van de ouders (CBS, 2002). Iemand die zich namelijk Nederlander voelt en als Nederlander wordt behandeld, kan door de definitie van het CBS echter als allochtoon worden beschouwd. Wanneer aan deze persoon zijn/haar mening wordt gevraagd over mensen van een andere afkomst dan de eigen afkomst - zoals in deze studie - geeft deze persoon zijn/haar mening over allochtonen. Deze persoon is volgens de CBS definitie echter zelf allochtoon; hierdoor wordt de mening over mensen van een andere afkomst dan de eigen afkomst ten onrechte gezien als een mening over autochtonen. Zulke mismatches leiden tot vertekende resultaten. Een tweede voordeel van het gebruik van de ervaren etniciteit boven de CBS-definitie komt naar voren wanneer de ouders geboren zijn in verschillende landen buiten Nederland. Bij de definitie van het CBS moet een arbitraire keuze gemaakt worden om de etniciteit te bepalen aan de hand van het geboorteland van de vader of het geboorteland van de moeder, het CBS kiest voor het geboorteland van de moeder. Deze keus is echter niet nodig wanneer etniciteit bepaald wordt aan de hand van de eigen perceptie.

3. Zo is de Blau Index voor een klas met $70 \%$ Nederlanders, $15 \%$ Turken en $15 \%$ Marokkanen hetzelfde als die voor een klas met 70\% Nederlanders, 15\% Antillianen en $15 \%$ Surinamers, namelijk 0,465. Terwijl de etnische compositie van de klas niet hetzelfde is.

\section{Literatuur}

Allport, G.W. (1954). The nature of prejudice. Cambridge, MA: AddisonWesley.

Baerveldt, C., Van Duijn, M.A.J., Vermeij, L. \& Van Hemert, D.A. (2004). Ethnic boundaries and personal choice. Assessing the influence of individual inclinations to choose intra-ethnic relationships on pupils' networks. Social Networks, 26(1), 55-74.

Bakker, J., Denessen, E., Pelzer, B., Veneman, M. \& Lageweg, S. (2007). De houding jegens klasgenoten: etnisch gekleurd? Een onderzoek naar de factoren van invloed op de attitude van basisschoolleerlingen jegens klasgenoten van verschillende etnische herkomst. Paper presented at the Onderwijs Research Dagen 2007.

Benjamini, Y. \& Hochberg, Y. (1995). Controlling the False Discovery Rate: A Practical and Powerful Approach to Multiple Testing. Journal of the Royal Statistical Society. Series B (Methodological), 57(1), 289-300.

Blau, P.M. (1977). Inequality and heterogeneity: Free Press New York.

Cameron, L., Rutland, A., Brown, R. \& Douch, R. (2006). Changing Children's Intergroup Attitudes Toward Refugees: Testing Different Models of Extended Contact. Child Development, 77(5), 1208-1219.

Centraal Bureau voor de Statistiek (2002). Allochtonen in Nederland 2002. Voorburg: CBS.

Centraal Bureau voor de Statistiek/Wetenschappelijk Onderzoek- en Documentatie Centrum (2006). Integratiekaart 2006. Voorburg/Den Haag: CBS/WODC. 
Coenders, M. (2001). Nationalistic Attitudes and Ethnic Exlusionism in a Comparative Perspective. An Empirical Study of Attitudes Toward the Country and Ethnic Immigrants in 22 Countries. Radboud University, Nijmegen.

Dekker, H., Malova, D. \& Hoogendoorn, S. (2003). Nationalism and Its Explanations. Political Psychology, 24(2), 345-376.

Dekker, H., Van der Noll, J. \& Capelos, T. (2007). Islamofobie onder jongeren en de achtergronden daarvan. Universiteit Leiden.

Gijsberts, M. \& Dagevos, J. (2005). Uit elkaars buurt. De invloed van etnische concentratie op integratie en beeldvorming. Den Haag: Sociaal en Cultureel Planbureau.

Hargreaves, D.H. (1967). Social Relations in a Secondary School. London: Routledge \& Kegan Paul.

Hello, E. (2003). Educational Attainment and Ethnic Attitudes. How to explain their relationship. Radboud University, Nijmegen.

Hello, E., Scheepers, P., Vermulst, A. \& Gerris, J.R.M. (2004). Association between Educational Attainment and Ethnic Distance in Young Adults. Socialization by Schools or Parents? Acta Sociologica, 47(3), 253275 .

Hox, J. (2002). Multilevel Analysis: Techniques and Application. Mahwah, New Jersey/London: Lawrence Erlbaum Associates, Publishers.

Junger-Tas, J. (1992). An empirical test of social control theory. Journal of Quantitative Criminology, 8(1), 9-28.

Ladd, G.W. (1990). Having Friends, Keeping Friends, Making Friends, and Being Liked by Peers in the Classroom: Predictors of Children's Early School Adjustment? Child Development, 61(4), 1081-1100.

Lubbers, M., Coenders, M. \& Scheepers, P. (2006). Objections to Asylum Seeker Centres: Individual and Contextual Determinants of Resistance to Small and Large Centres in the Netherlands. European Sociological Review, 22(3), 243.

Luhtanen, R. \& Crocker, J. (1992). A Collective Self-Esteem Scale: Self-Evaluation of One's Social Identity. Personality and social psychology bulletin, 18(3), 302-318.

McLaren, L.M. (2003). Anti-Immigrant Prejudice in Europe: Contact, Threat Perception, and Preferences for the Exclusion of Migrant. Social Forces, 81(3), 909-936.

Meulen, R. van der (2007). Alle Menschen werden Brüder Lidmaatschap van sportverenigingen, vriendschappen, kennissenkringen, en interetnisch vertrouwen. Mens en Maatschappij, 82(2), 155-176.

Meulen, R. van der \& Ultee, W. (2006). Overbrugger of onderscheider? Hoe frequent ontstaat interetnisch contact via the sportverenigingsleven in Nederland? Tijdschrift voor sociologie, 27(2), 109-130.

Nesdale, D. (1999). Developmental Changes in Children's Ethnic Preferences and Social Cognitions. Journal of Applied Developmental Psychology, 20(4), 501-519. 
Nesdale, D. \& Todd, P. (200o). Effect of contact on intercultural acceptance: a field study. International Journal of Intercultural Relations, 24(3), 341-36o.

Newman, R. S. \& Schwager, M.T. (1993). Students' Perceptions of the Teacher and Classmates in Relation to Reported Help Seeking in Math Class. The Elementary School Journal, 94(1), 3-17.

Nigbur, D., Brown, R., Cameron, L., Hossain, R., Landau, A., Le Touze, D. et al. (2007). Acculturation, well-being and classroom behaviour among white British and British Asian primary-school children in the south-east of England: Validating a child-friendly measure of acculturation attitudes. University of Sussex.

Peters, D., Haest, M. \& Walraven, G. (2008). Perspectieven voor het tegengaan van etnische segregatie in het voortgezet onderwijs. Amsterdam: Walraven \& Haest.

Pettigrew, T.F. (1998). Intergroup contact theory. Annual Reviews in Psychology, 49(1), 65-85.

Pettigrew, T.F. \& Tropp, L.R. (2006). A Meta-Analytic Test of Intergroup Contact Theory. Journal of Personality and Social Psychology, 90(5), 751783.

Postma, R. (2007). Wederzijdse tolerantie onder allochtone en autochtone MBOscholieren in Friesland. Radboud Universiteit, Nijmegen.

Prinsen, M. \& Verkuyten, M. (2006). De Nederlandse samenleving. Onderzoek onder scholieren in Nederland. Unpublished Questionnaire. Universiteit Utrecht.

Rosenberg, M. (1965). Society and the adolscent self-image. Princeton: Princeton University Press.

Rubin, D.B. (1987). Multiple imputation for nonresponse in surveys Wiley series in probability and mathematical statistics. Probability and mathematical statistics. New York: Wiley.

Rushton, M. (2007). A Note on the Use and Misuse of the Racial Diversity Index. School of Public and Environmental Affairs Indiana University. [red. Policy Studies Journal, 36(3), 445-459. ??]

Scheepers, P., Gijsberts, M. \& Coenders, M. (2002). Ethnic Exclusionism in European Countries. Public Opposition to Civil Rights for Legal Migrants as a Response to Perceived Ethnic Threat. European Sociological Review, 18(1), 17-34.

Sniderman, P.M. \& Hagendoorn, L. (2007). When ways of life collide. New Jersey: Princeton University Press.

Steinberg, L. \& Silverberg, S.B. (1986). The Vicissitudes of Autonomy in Early Adolescence. Child Development, 57(4), 841-851.

Van Dick, R., Wagner, U., Pettigrew, T.F., Christ, O., Wolf, C., Petzel, T. et al. (2004). Role of perceived importance in intergroup contact. Journal of personality and social psychology, 87(2), 211-227. 
Tubergen, F. van (2006). Migratiesociologie in Nederland. Suggesties voor vooruitgang. In G. Engbersen \& J. de Haan (Eds.), Balans en toekomst van de sociologie. Amsterdam: Pallas Publications.

Verkuyten, M. (2005). Ethnic Group Identification and Group Evaluation Among Minority and Majority Groups: Testing the Multiculturalism Hypothesis. Journal of Personality and Social Psychology, 88(1), 121-138.

Verkuyten, M. (2007). Ethnic In-Group Favoritism Among Minority and Majority Groups: Testing the Self-Esteem Hypothesis Among Preadolescents. Journal of Applied Social Psychology, 37(3), 486-500.

Verkuyten, M. \& Thijs, J. (2002a). Multiculturalism among minority and majority adolescents in the Netherlands. International Journal of Intercultural Relations, 26, 91-108.

Verkuyten, M. \& Thijs, J. (2002b). Racist victimization among children in The Netherlands: the effect of ethnic group and school. Ethnic and Racial Studies, 25(2), 310-331.

Vrij, A., Akehurst, L. \& Smith, B. (2003). Reducing ethnic prejudice: an evaluation of seven recommended principles for incorporation in public campaigns. Journal of Community \& Applied Social Psychology, 13(4), 284-299.

Yogev, A., Ben-Yehoshua, N.S. \& Alper, Y. (1991). Determinants of Readiness for Contact with Jewish Children among Young Arab Students in Israel. The Journal of Conflict Resolution, 35(3), 547-562. 


\section{Appendix A}

\section{Tabel 3 Gebruikte stellingen voor de variabele ervaren culturele dreiging}

Autochtone Nederlanders moeten accepteren dat Nederland uit allerlei culturele en godsdienstige groepen bestaat*

Mensen die er zelf voor kiezen om naar Nederland te komen, dienen zich aan te passen

Het is het beste voor Nederland als allochtonen hun culturele achtergrond zo snel mogelijk vergeten

Hoe meer culturen er zijn, hoe beter het is voor Nederland*

Allochtonen mogen hun eigen waarden en normen behouden, ook buiten huis*

Nieuwkomers moeten zoveel mogelijk hun eigen cultuur opgeven en de cultuur van Nederlanders overnemen

Nederland is van oorsprong een Christelijk land en dat moet ook zo blijven

In de samenleving moet geen enkele groep meer te zeggen hebben dan andere groepen*

Alle culturele groepen moeten gelijke kansen krijgen in Nederland*

Nieuwkomers hebben net zo veel te zeggen over de toekomst als mensen die hier geboren zijn*\#

* Stelling is gehercodeerd voor de analyses

\# Stelling is niet opgenomen in de schaal

Tabel 4 Gebruikte stellingen voor de variabele zelfwaardering

Over het algemeen ben ik tevreden met mijzelf

Soms denk ik dat ik niks waard ben*

lk denk wel dat ik een paar goede kwaliteiten heb

Ik kan de meeste dingen net zo goed als de meeste andere mensen

Ik heb het gevoel dat ik niet veel heb om trots op te zijn*

Soms voel ik mij nutteloos*

Ik heb het gevoel dat ik evenveel waard ben als anderen

Ik zou willen dat ik meer respect voor mezelf had*

Ik voel me soms een mislukkeling*

Ik ben positief over mijzelf

* Stelling is gehercodeerd voor de analyses 